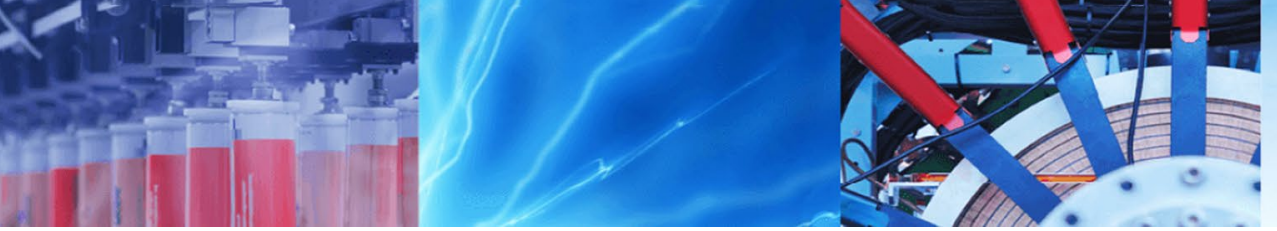

Review Paper

\title{
Silicon-air batteries: progress, applications and challenges
}

\author{
Rishabh Bansal $^{1} \cdot$ Prajwal Menon $^{1} \cdot$ R. C. Sharma ${ }^{1}$ (I)
}

Received: 1 April 2020 / Accepted: 15 May 2020 / Published online: 29 May 2020

(c) Springer Nature Switzerland AG 2020

\begin{abstract}
Silicon-air battery is an emerging energy storage device which possesses high theoretical energy density $\left(8470 \mathrm{Wh} \mathrm{kg}^{-1}\right)$. Silicon is the second most abundant material on earth. Besides, the discharge products of silicon-air battery are nontoxic and environment-friendly. Pure silicon, nano-engineered silicon and doped silicon have been found potential candidate for anode. Meso-porous meso-cellular carbon having optimal pore size and imbibed with $a-\mathrm{MnO}_{2}$ nanowires catalyst is found the most promising cathode. Several technical, design and corrosion problems associated with $\mathrm{Si}$-air battery system have to be resolved for its mass scale deployment. This review presents comprehensive information on Si-air battery technology.
\end{abstract}

R. C. Sharma, rcsharma@dce.ac.in | 'Department of Applied Chemistry, Delhi Technological University, Delhi 110042, India. 


\section{Graphic abstract}

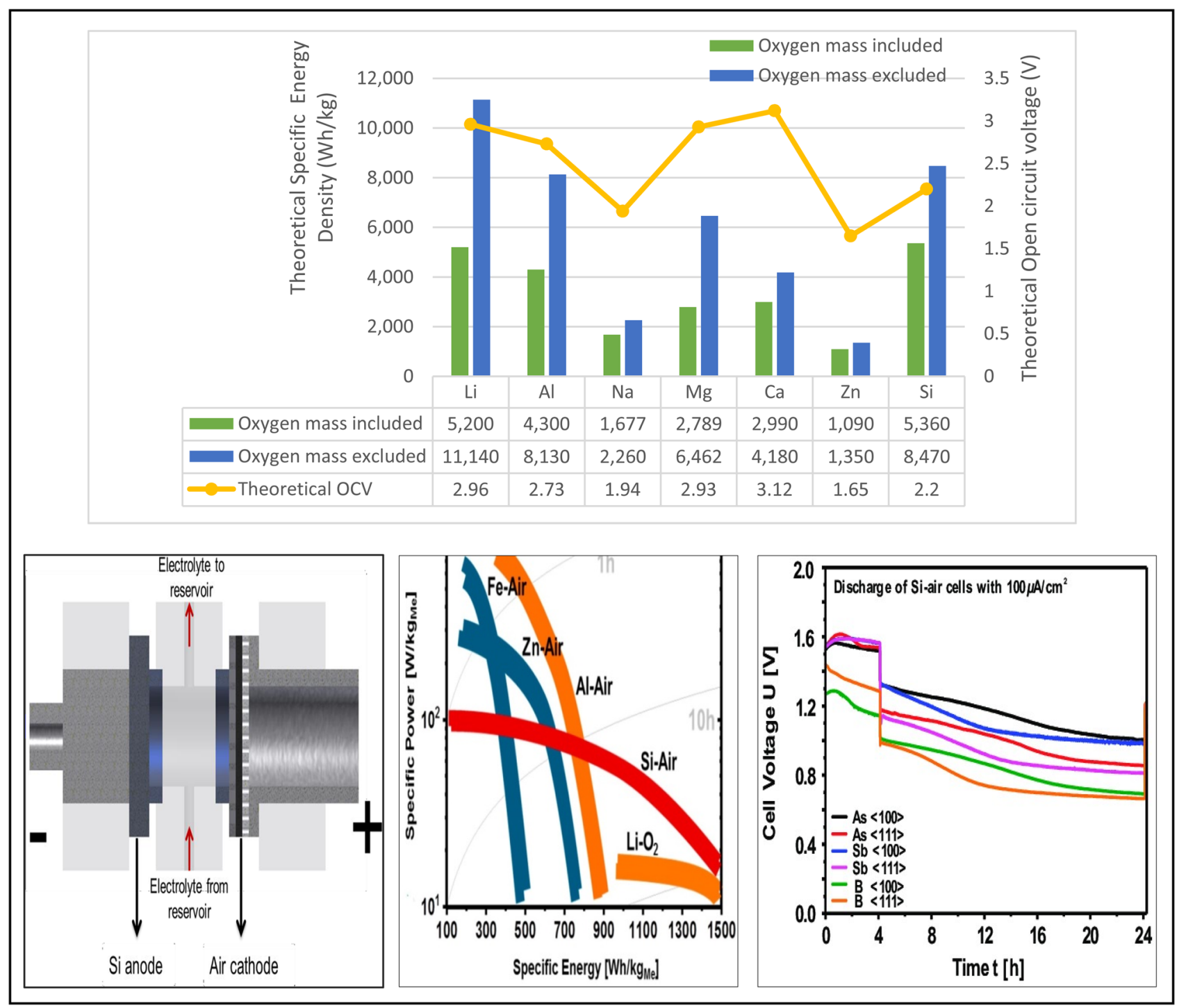

Keywords Silicon · Si-air battery $\cdot$ Ionic liquids $\cdot$ Gel polymer electrolyte $\cdot$ Oxygen reduction catalyst $\cdot$ Heteroatom doped carbons

\section{Introduction}

Isaac Newton and Michael Faraday have given us the intellectual tools to wheel the battery of innovations for clean energy and efficient techno-development of global community. Extensive usage of energy coupled with global climate change has necessitated the growth of renewable energy production and storage systems. World-wide interest in electric vehicles (EVs) has focused on miniaturization of light weight rechargeable batteries. Li-ion batteries with high energy efficiency and more cyclic capabilities has become the most promising candidate for EV applications. However, its low storage capacity $\left(100-200 \mathrm{Wh} \mathrm{kg}^{-1}\right)$, safety issues and high cost has led to extensive research activities to find alternative energy storage technology. Metal-air battery systems such as Li-air, $\mathrm{Mg}$-air, $\mathrm{Zn}$-air, $\mathrm{Al}$-air and $\mathrm{Si}$-air are highly promising for powering automobiles, industrial equipment, computers, electronic device, hearing aids and a large number of utility items [1-8]. Apart from possessing high energy density (400-1700 $\mathrm{Wh} \mathrm{kg}^{-1}$ ), metal-air batteries are compact, low cost, lighter and environment friendly [9-15]. The reason 
for high energy density possessed by metal-air batteries is its cathode which operates on oxygen present in the air during discharge, replacing costly chemicals used in present Li-ion batteries. Early work on metal-air batteries encountered the problems associated with the material at the air cathode surface, thermal management system along with various technical problems associated with anodes. Theoretical specific energy densities and open circuit voltages of metal-air battery systems are shown in Fig. 1.

Lithium metal is considered to be the best candidate as anode material because of its high theoretical specific energy $\left(3860 \mathrm{Ah} \mathrm{kg}^{-1}\right)$, low density $\left(0.59 \mathrm{~g} \mathrm{~cm}^{-3}\right)$ and the lowest electrode potential ( $3.045 \mathrm{~V}$ vs. SCE). Si-air battery has comparable specific energy density (5360 $\mathrm{Wh} \mathrm{kg}^{-1}$ ) with $\mathrm{Li}$-air battery $\left(5200 \mathrm{Wh} \mathrm{kg}^{-1}\right)$. Also, silicon (28.2\%) is more abundant in earth's crust when compared with lithium (0.002\%) and is also less expensive than lithium metal. The practical performances of some battery systems including metal air batteries have been represented in the form of Ragone plots [16] (Fig. 2). It may be noted from the Ragone plots that metal-air batteries deliver higher specific energy while Li-ion battery provides the best power capability. Also, $\mathrm{Li}$-air and $\mathrm{Si}$-air batteries provide specific energies of the same order but there is large difference in their specific power capabilities. Moreover, rechargeability of $\mathrm{Si}$-air batteries is a challenging task.
Fig. 1 Comparison of theoretical specific energy densities and open circuit voltages (OCVs) of different metal-air batteries [10]
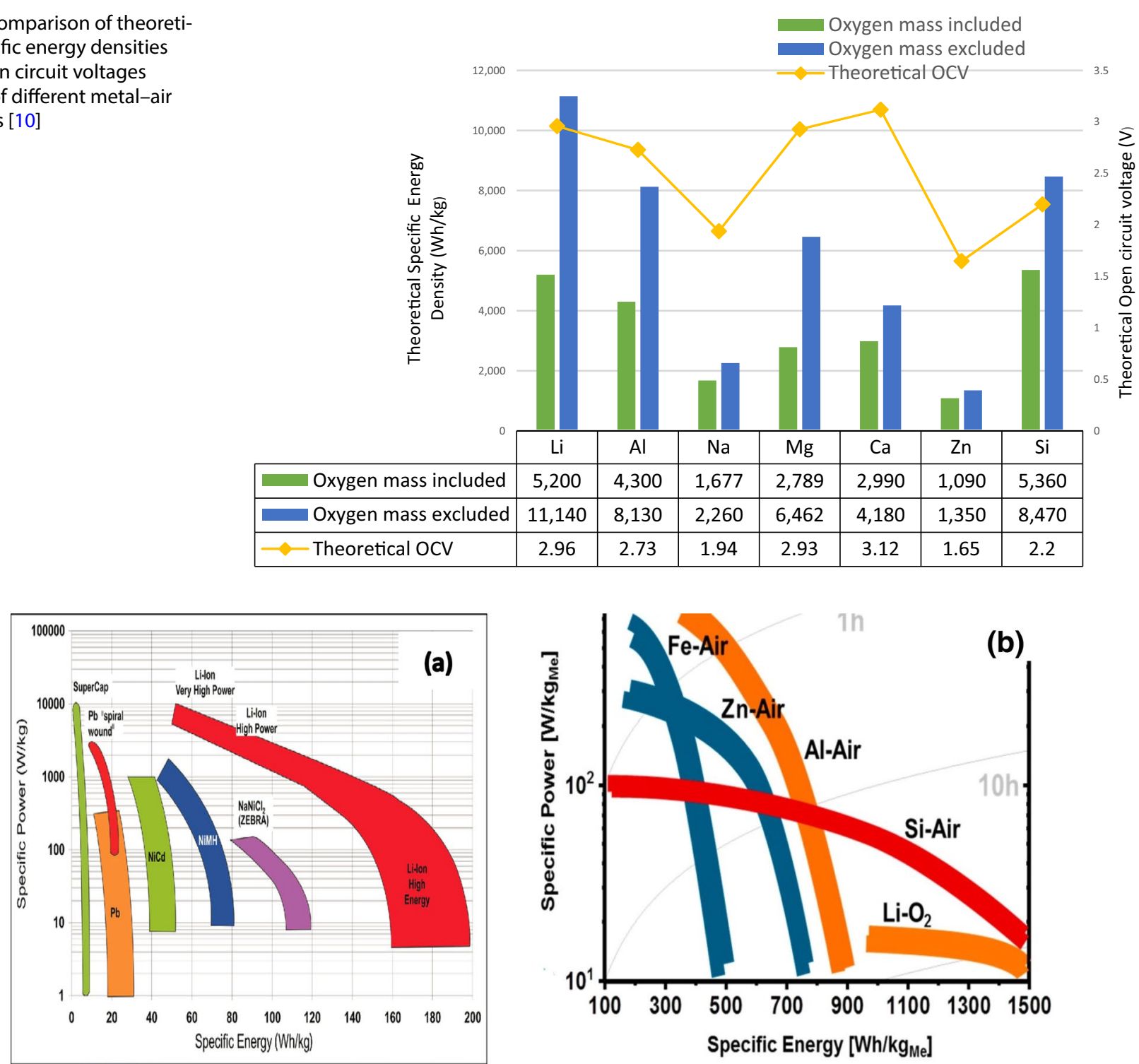

Fig. 2 a Ragone plot [16] for the important batteries systems; b the comparison of different metal air battery systems. The typical logarithmic axes of Ragone plot $\mathbf{a}$ is changed to logarithmic $y$ and linear $\mathbf{x}$ in $\mathbf{b}$ in order to represent the differences between the metal-air batteries 
Si-air battery research was initiated by Prof. Yair-Ein-Eli and team at the Technion-Israel Institute of Technology in 2009 [17]. This novel type of primary battery had an ideal specific energy of $E=8470 \mathrm{Wh} \mathrm{kg}^{-1}$ and a long-term stable voltage of 1.0-1.2 V. It consisted of doped silicon wafers as fuel, an air cathode, and a specially synthesized ionic liquid $\left(\mathrm{EMI} \cdot(\mathrm{HF})_{2} \cdot 3 \mathrm{~F}\right)$ as electrolyte.

\section{Silicon-air cell construction}

Yair-Ein-Eli et al. [17] used a silicon single-crystal anode, air cathode and specially synthesized room temperature ionic liquid (EMI.(HF) $2 \cdot 3 \mathrm{~F})$ as electrolyte. Graphic representation of cell assembly is shown in Fig. 3. The cell is made up of three plastic plates. The first plate is made of multiple pieces of silicon wafers of size $1 \mathrm{~cm} \times 1 \mathrm{~cm}$ which were pressed into a viton O-ring. The exposed area of silicon

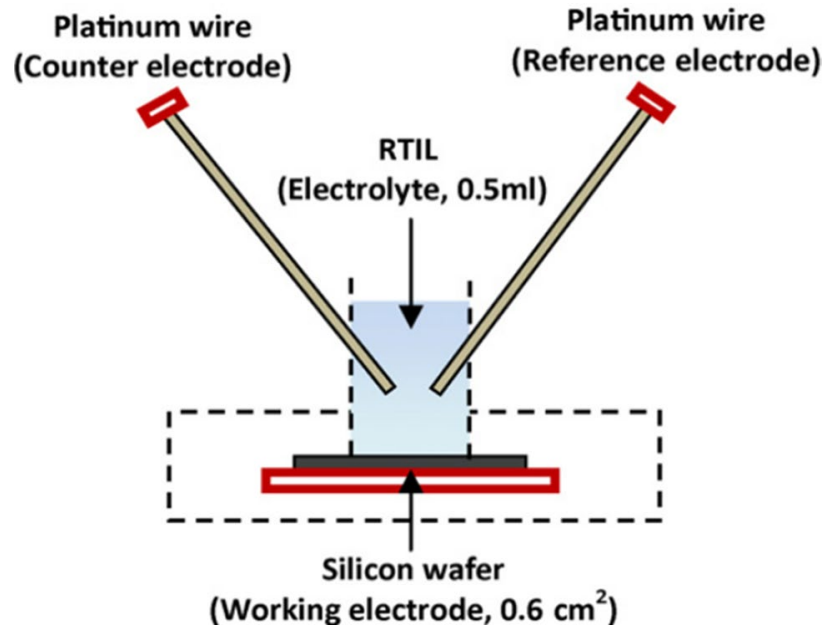

Fig. 3 Silicon-air cell assembly [17] wafers is $0.5 \mathrm{~cm}^{2}$. The second sheet consists of circular sheets of graphitic air electrodes having $0.5 \mathrm{~cm}^{2}$ exposed area. The third sheet is employed to make an outer circle periphery which is used to make electrical contact. High grade copper wires are used for making terminal contacts. Si wafer anodes were pre-treated before cell construction; the treatment involved immersion of Si-wafers in HF solution $\left(1 \mathrm{HF}: 5 \mathrm{H}_{2} \mathrm{O}\right)$ for $10 \mathrm{~s}$ to remove surface oxide layer followed by cleaning with de-ionized (DI) water and finally drying in a nitrogen stream. The anode-separator-cathode is sandwiched and $0.5 \mathrm{ml}$ of the ionic liquid was added to complete the cell assembly. For adequate wetting of all the components, the cell assembly is maintained at OCV for $4 \mathrm{~h}$ during which no current was drawn from the cell assembly. The cell was later used to draw current to initiate the discharge process.

\section{Anode for Si-air battery}

\subsection{Silicon wafers}

Doped silicon wafers are widely used as anode material for $\mathrm{Si}$-air batteries. Silicon $<100>$ crystals, both moderately doped ( $\mathrm{n}$-type) and profoundly doped $\left(\mathrm{n}^{++}\right.$-type), are held with a screwed back stainless steel contact plate electroplated with thin layer of gold [18]. The corrosion rates for various types of silicon material as anode is shown in Fig. 4.

Silicon corrosion rates and polarization voltammograms form a basis for anode selection. On one hand, $\mathrm{p}^{++}$silicon has lower corrosion rates and better cell voltage at high currents whereas on the other hand, $\mathrm{n}^{++}$silicon has higher $\mathrm{OCV}$ and better cell voltages at low currents. Even though $\mathrm{n}^{++}$doped Si exhibited greater corrosion rates, it has been a subject of interest due to its greater cell voltage at low values of current.
Fig. 4 Silicon electrode corrosion rates in EMI.(HF) $2.3 F$ [19]

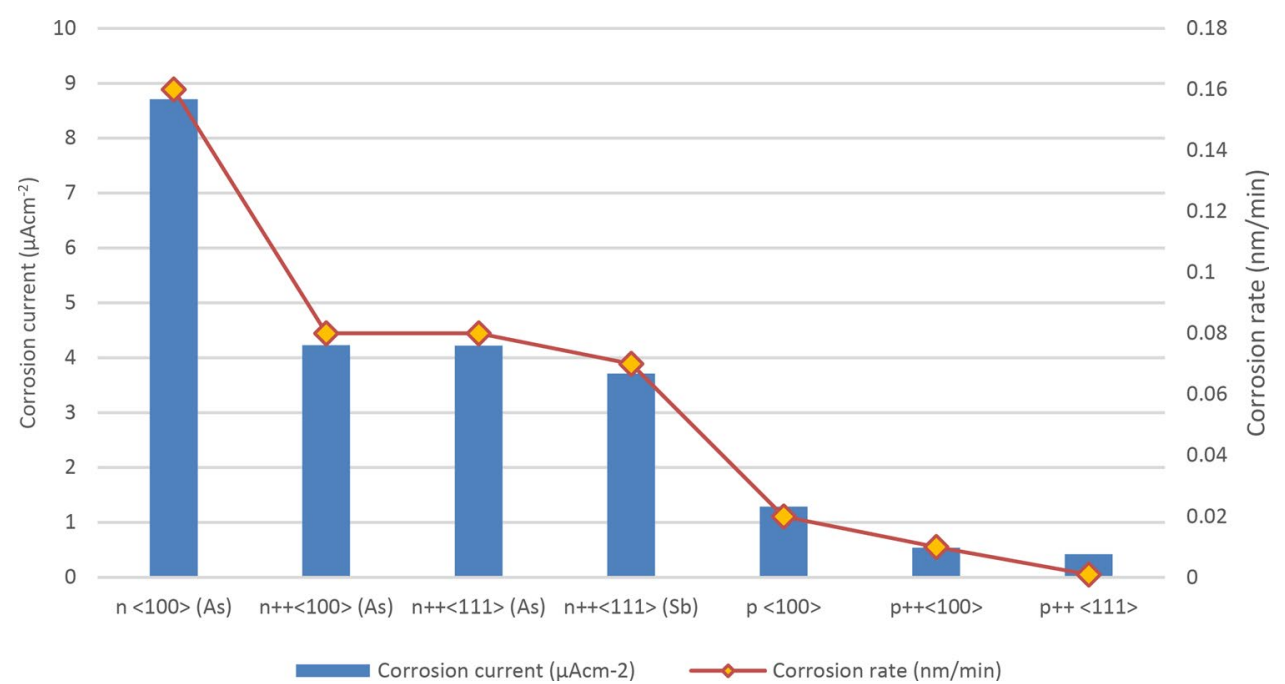




\subsection{Nanostructured silicon}

Nanostructured silicon/arrays of silicon nanowires or nanorods have been used as anode material in lithiumion batteries to overcome cracking and pulverization $[20,21]$. A robust electrical contact is maintained when silicon nanowires are used as anode material since each nanowire is directly connected to the current collecting substrate. Mingyuan Ge et al. [22] reported that porous silicon nanowires synthesized by direct etching of borondoped silicon wafers possesses high porosity and electron conductivity. As anode material, these nanowires exhibit high structure stability, higher electrochemical performance and long cycle life. Even after 250 cycles, the capacity remains stable above 2000,1600 , and $1100 \mathrm{mAh} \mathrm{g}^{-1}$ at current rates of 2,4 , and $18 \mathrm{~A} \mathrm{~g}^{-1}$ respectively. Zhong et al. [23] used nanostructured silicon as the anode material in the design of $\mathrm{Si}$-air battery with alkaline electrolyte. Nanoengineered silicon anodes have been found to increase the reversible charge capacity and longer cycle life for new generation batteries. The surface of the silicon wafer is reformed by metal-assisted electro less etching method to facilitate formation of micro-porous layer on the silicon wafers [24-27]. The native oxide layer is removed by immersing the clean silicon pieces into a buffered oxide etching (BOE) agent.

\subsection{Doped silicon}

Silicon doped with Arsenic(As), Antimony(Sb) and Boron(B) with different orientations, i.e. $<100\rangle$ and $\langle 111\rangle$, was used as anode by Durmus et al. [28, 29]. The following six types of silicon anodes were used.

i. As-doped [Crystal family type $<100>$ ] (Resistivity: $0.001-0.007 \Omega \mathrm{cm}$ )

ii. As-doped [Crystal family type <111>] (Resistivity: $0.001-0.010 \Omega \mathrm{cm}$ )

iii. Sb-doped [Crystal family type $<100>$ ] (Resistivity: $0.007-0.020 \Omega \mathrm{cm}$ )

iv. Sb-doped [Crystal family type <111>] (Resistivity: $0.022-0.028 \Omega \mathrm{cm}$ )

v. B-doped [Crystal family type $<100>$ ] (Resistivity: $0.001-0.005 \Omega \mathrm{cm}$ )

vi. B-doped [Crystal family type $<111>$ ] (Resistivity: $0.002-0.016 \Omega \mathrm{cm}$ )

Two stage surface treatment of the doped wafer is carried out with argon/oxygen plasma to remove organic contaminants. The native oxide layers are removed from the wafer surfaces with the help of argon/sulfur hexafluoride plasma. The cell assembly is fabricated and kept for $4 \mathrm{~h}$ in a climate chamber which is maintained at $25^{\circ} \mathrm{C}$ and $50 \%$ relative humidity. During this period no current is drawn and the silicon-air cells are held at their open-circuit voltage (OCV) before carrying out discharge process.

The 3D images ${ }^{1}$ (Fig. 5) revealed that the surface characteristics of $<100>$ vs. $<111>$ oriented Si anodes vary significantly at low discharge currents. With both, arsenic-doped and antimony-doped Si anodes having orientation $\langle 100\rangle$, homogeneous 3D images are observed while with $<111>$ oriented Si anode, 3D images consists of polygons. When cells are discharged at $0.1 \mathrm{~mA} \mathrm{~cm}^{-2}$ for $20 \mathrm{~h}$, it is observed that the surface characteristics for corresponding orientation at mesoscale are almost similar for As- and Sb-doped Si anodes. 3D images of B-doped ( $p$-type) and B-doped (n-type) Si anodes, under similar conditions of discharge, exhibited large differences in their surface characteristics. B-doped Si anodes with $<100>$ orientation presented a homogeneous surface with a few individual small pores, while $<111>$ oriented anodes showed a grain like structure.

Thus, the surface characteristics of B-doped Si anodes differ significantly from As- and Sb- doped Si anodes, indicating possibly two types of discharge mechanism at the anode surfaces. The studies on different anodes for $\mathrm{Si}$-air batteries recommend that $\mathrm{n}^{++}$doped $\mathrm{Si}$ anode may be a better choice for higher cell voltage and low current applications while nano-engineered $\mathrm{Si}$ anode can be used in applications where higher charge capacity and longer cycle life is needed predominantly.

\section{Cathode for Si-air battery}

\subsection{Air cathode}

Air cathode composition and structure play an important role in $\mathrm{Si}$-air battery performance. Porous carbon imbibed with a catalyst, and a polymer binder is used as the air cathode. The specific capacity of an air electrode depends on several factors. Cheng et al. [30] and Xiao et al. [31] studied the effect of surface areas of different graphitic materials on specific capacity of the battery and it was found to be proportional to the surface area. Yang et al. [32] investigated the effect of pore size on specific capacity of $\mathrm{Si}$-air cell and reported that air cathode with mesoporous meso-cellular carbon foam have higher specific capacity. Instead of too large or too small, optimum pore size is recommended. The thickness of the air cathode also

\footnotetext{
${ }^{1}$ High resolution 3D images of silicon wafers may be taken using a confocal laser scanning microscope (OLS4100, Olympus Corp., Japan), having magnification (Optical and Digital) in the ranges from $108 \times$ to $17,280 \times$ which can resolve up to $10 \mathrm{~nm}$ in size in the $z$ direction and $120 \mathrm{~nm}$ in the $\mathrm{x}-\mathrm{y}$ plane.
} 
Fig. 5 3D images of As-doped Si electrode with $<100>$ orientation. a optical microscopy image from the surface; $\mathbf{b}$ green square in $\mathbf{a}$ as imaged by AFM; $c$ a line scan of green square position, as indicated in $\mathbf{b} ; \mathbf{d} 3 \mathrm{D}$ reconstruction of $\mathbf{b}$
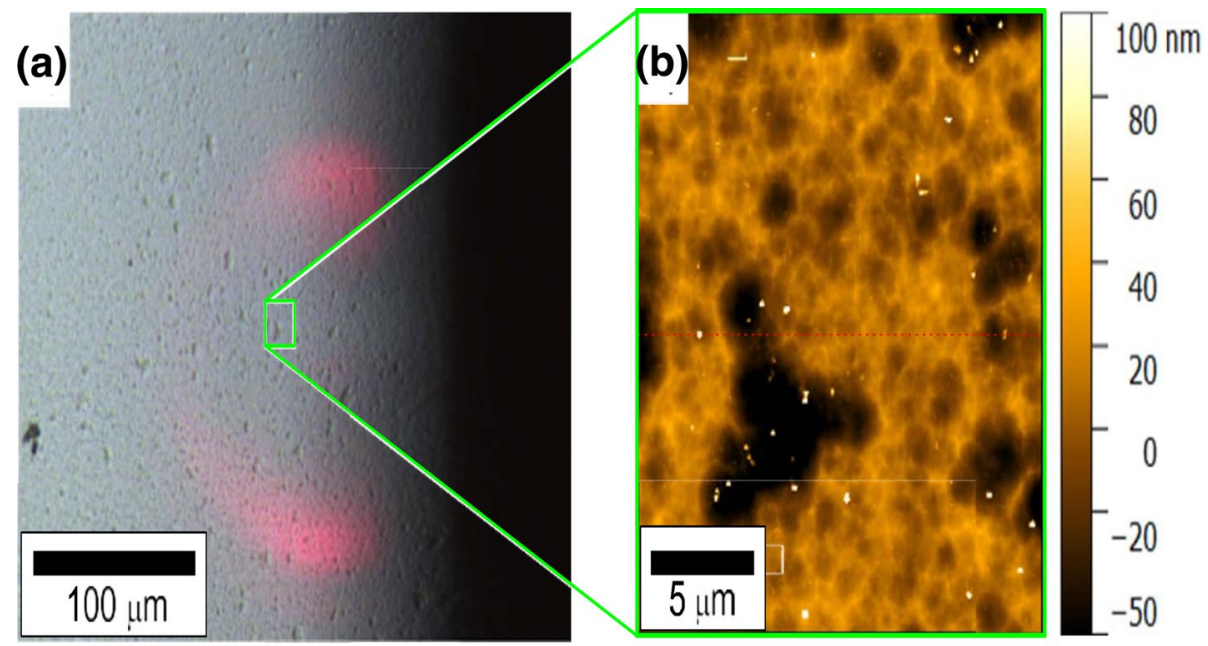

(c)

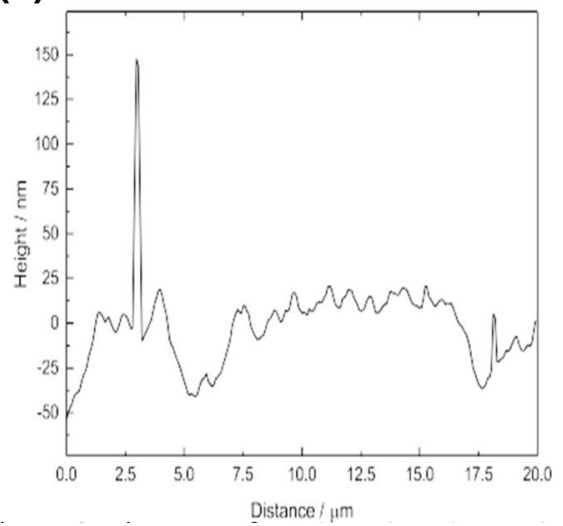

(d)

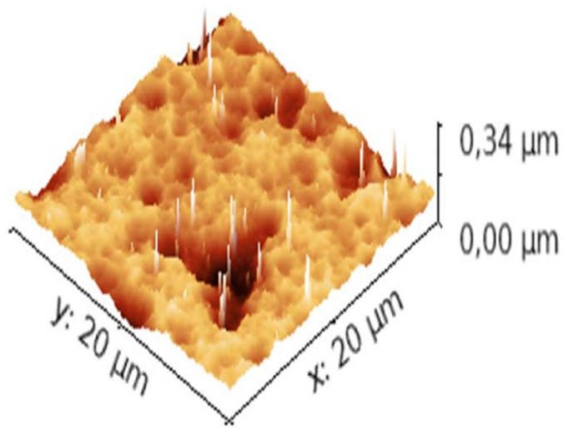

plays an important role. Zhang et al. [33] found that the cells with thicker electrodes have lower specific capacity, which is endorsed to slow oxygen diffusion through thicker air cathodes.

Beattie et al. [34] reported that specific capacity of the cells is inversely proportional to the amount of carbon loaded in the cathode. Another factor that affects the electrochemical performance of an air electrode is oxygen diffusion through the air electrode, which can be facilitated by increasing oxygen pressure. Read et al. [35], Yang and Xia [36] and Tran et al. [37] reported that the specific capacity linearly increases with the oxygen pressure. The porosities, wettability and electrical contact of electrodes are determined by the ratio of carbon, catalyst, and polymer, which ultimately affects the electrochemical performance of $\mathrm{Si}$-air cells.

\subsection{Catalysts for air cathode}

\subsubsection{Noble metals}

Noble metals such as platinum and Pt-based alloys have been used as oxygen reduction reaction electro catalysts for many decades. The nanoparticles of PtAu exhibited high stability and exemplary catalytic activity for carbon air cathodes of fuel cells and battery systems. Several studies [38-41] reported that ORR properties of Pt-based catalysts can be further improved by changing the size of the particles to nano scale and changing the surface characteristics of Pt-based nanostructures. When alloyed with other noble or transition metals, the performance of Pt based catalysts can be improved along with a reduction in cost [42-47].

\subsubsection{Carbonaceous materials}

Graphene and carbonaceous materials have been preferred as electro catalysts for air cathode of Si-air battery systems. These have found application as metal free catalyst or catalyst support because of their superior properties which include low cost, widespread availability, low electrical resistivity, very big surface areas and noble stability under severe conditions [48-64]. However, it has been reported that the electrochemical performance of these types of electro catalysts is highly dependent on their structure, morphology, pore size, and wall thickness. 
Appropriate pre-treatment of the surface of carbonaceous materials improves its functionality and enhance the durability of ORR catalysts.

\subsubsection{Transition-metal oxides}

High spin transition-metal complexes having spinels and perovskites morphology represents another class of cathode electro catalysts, highly useful in Si-air battery system [65-67]. These have shown excellent stability in alkaline medium whereas the stability in acidic electrolyte is relatively poor. Oxides of titanium as co-catalysts have further enhanced the activity of noble metals and its alloys with non-precious metals. Chen et al. [68] examined titanium nitrides and reported that these are highly efficient cathode electro catalysts. Transition metal carbides act as promising supports to promote the stability and activity of Pt- based ORR electro catalysts [69, 70]. The variable valence of transition metals such as $\mathrm{Mn}, \mathrm{Co}$, Fe and Ni gives rise to multiple structures to the oxides [71]. Mn-based oxides have been extensively studied as electro catalysts for air-electrodes. Electrochemically active manganese oxides such as $\mathrm{MnO}_{2}, \mathrm{Mn}_{2} \mathrm{O}_{3}, \mathrm{Mn}_{3} \mathrm{O}_{4}$, and $\mathrm{Mn}_{5} \mathrm{O}_{8}$ exhibits high catalytic activity [72-75].

\subsubsection{Inorganic-organic composites}

The integration of organic matrix with nano-sized metal constitutes inorganic-organic composites. It is another class of materials that are used as noble metal-free electro catalysts for oxygen electrochemistry [76-84]. The nonprecious $\mathrm{Ni} / \mathrm{Fe}$ metals easily form composite with polyoxometalate (POM) and o-Anisidine (OA) and have exhibited high catalytic activity and stability towards oxygen evolution reaction (OER). A competition between metal cation takes place to make complex with composite. Nanostructured $\mathrm{Ni}_{x} \mathrm{Fe}_{y}(\mathrm{OH})_{2}$ powders, coated onto various substrate with the aid of polymeric binders, have shown high catalytic activity in alkaline electrolytes. Such composites can be prepared by pyrolysis of metal, nitrogen and carbon as these is not stable in strong acidic or alkali media. The catalytic activities of these composites depend on several parameters which include the metal, the precursors, the substrate and the synthesis method [85]. Nano engineered metal composites with heterocyclic conjugated polymers (polyaniline, polypyrrole and poly(3,4-ethylenedioxithiophene) have also been used as electro catalysts $[78,86$, 87]. These composites have advantage over other types of catalysts as the incorporation of metal ions in matrices creates large number of active sites [86]. Further, the bridges between matrix and metal promote physical and electrical contact [87]. Inorganic-organic composites such as
FeCo-EDA catalysts have shown outstanding ORR activity in alkaline electrolytes and exhibits nearly 3 times higher mass activity than commercial Pt/C catalyst [88].

\subsubsection{Hetero-atom doped carbons}

Heteroatom (N \& S) doped carbon nano-materials [89-92] are the most promising ORR catalyst as it markedly reduces the cost and increase the efficiency of metal-air battery systems/fuel cells. Vertically aligned nitrogen-doped carbon nanotube (VA-NCNT) arrays can act as a metal-free electrode to catalyze a $4 \mathrm{e}^{-}$ORR process with a three times higher electro catalytic activity and better long-term stability than commercially available $\mathrm{Pt} / \mathrm{C}$ electrodes in an alkaline cell [89]. These carbon-based metal-free ORR catalysts are also free from the $\mathrm{CO}$ poisoning and methanol crossover effects. Choi et al. $[93,94]$ synthesized nitrogen and sulfur-doped carbons and studied their electro catalytic activity towards oxygen reduction reactions (ORR). The carbon catalyst synthesized from cysteine and dual-doped with nitrogen and sulfur, exhibited the highest onset potential $(0.55 \mathrm{~V}$ vs. $\mathrm{Ag} / \mathrm{AgCl})$ and electrochemical activity in acidic media, $-0.2 \mathrm{~mA}$ (at $0.2 \mathrm{~V} \mathrm{vs}$. Ag/ $\mathrm{AgCl})$, which is about $43 \%$ of that of commercial Pt/C (40 wt\%). From XPS studies they showed that in the carbon catalyst, sulfur was doped as sulfate or sulfonate. It was concluded that not only nitrogen doping but also sulfur doping of carbon improve its electro catalytic activity towards ORR. Zhang et al. [95, 96]. synthesized graphenebased B/N co-doped carbon nano sheets (G-CBP). It was argued that high surface area, unique $2 \mathrm{D}$ sheet nanostructure, and high heteroatom-doping contents $(5.4 \% \mathrm{~B}$ and $5.3 \% \mathrm{~N}$ ) of G-CBP results into an excellent electrochemical performance for the oxygen reduction reaction under alkaline conditions ( $0.1 \mathrm{M} \mathrm{KOH})$.

\subsection{Oxygen reduction reaction (ORR) in air electrode}

Polytetrafluoroethylene (PTFE) with activated carbon black $\left(0.45-0.5 \mathrm{~g} \mathrm{~cm}^{-2}\right.$ loaded) is used as air cathode [17]. The mixture is encapsulated onto a nickel 200 mesh under high pressure and manganese dioxide is added as cathode catalyst. The reduction of oxygen occurring at the air electrode is said to proceed either as 4 electrons or 2 electrons as shown:

$\mathrm{O}_{2}+4 \mathrm{e}^{-} \leftrightharpoons 2 \mathrm{O}^{2-}$

$\mathrm{O}_{2}+2 \mathrm{e}^{-} \leftrightharpoons \mathrm{O}_{2}^{2-}$ 
The scanning electron microscopy (SEM) micrographs of air cathode revealed that activated carbon on cathode is covered with sedimentation during the battery discharge.

Peter Jakes et al. [18] studied the role of manganese oxide $\left(\mathrm{MnO}_{2}\right)$, which acts as an oxygen- reduction reaction (ORR) catalyst on $\mathrm{Si}$-air battery performance. The chemical state of $\mathrm{Mn}$ ions in the $\mathrm{MnO}_{2}$ catalysts was examined by XP and EPR spectroscopy. It was inferred from the results that during the discharge process, $\mathrm{MnO}_{2}$ also undergo changes during an electrochemical reaction when the electrolyte has fluoride ions, commonly present in the RTIL.

$\mathrm{MnO}_{2}+8(\mathrm{HF})_{3} \mathrm{~F}+2 \mathrm{e}^{-} \leftrightharpoons \mathrm{MnF}_{2}+10(\mathrm{HF})_{2} \mathrm{~F}+2 \mathrm{H}_{2} \mathrm{O}$

The formation of non-ORR catalyst $\mathrm{MnF}_{2}$ results in the loss of available catalytic sites and also lowers the ionic conductivity of the electrolyte. The change of $\mathrm{MnO}_{2}$ to $\mathrm{MnF}_{2}$ greatly affects the Si-air battery performance by limiting the discharge capacity and inhibiting the cell discharge of Si-air battery. The electrochemical changes at air cathode are quite complex and complete understanding will require extensive studies with different catalyst and electrode/electrolyte systems. However, studies on new catalyst and new ionic solvent may lead to a suitable system to better understand the phenomenon.

\section{Electrolytes for Si-air battery}

\subsection{Room temperature ionic liquid (RTIL)}

A room temperature ionic liquid (RTIL), $\mathrm{EMI}$.(HF) ${ }_{2} \cdot 3 \mathrm{~F}$ is the most common type of electrolyte used in a $\mathrm{Si}$-air battery. The EMI.(HF) $)_{2} \cdot 3 \mathrm{~F}$ is synthesised by a reaction of 1-ethyl3-methylimidazolium chloride and hydrogen fluoride by Hagiwara et al. [97]. The electrolyte has low viscosity and high conductivity amongst all RTILs with $100 \mathrm{mS} \mathrm{cm}^{-1}$, besides chemical stability in air and high tolerance at extreme relative humidity conditions $[98,99]$. The schematic of first experimental Si-Air Battery that utilised RTIL as the electrolyte is shown in Fig. 6.

Potentiodynamic polarization studies of the RTIL-silicon wafer couples (anodic half-cell) and of the IL-air electrode (cathodic half-cell) is used to evaluate EMI.(HF) $2.3 \mathrm{~F}$ as a viable candidate for electrolyte in a $\mathrm{Si}$-air battery is shown in Fig. 7.

The half-cell reactions, crystallization reaction and overall reaction when two anions of RTIL contribute to the oxidation of silicon at anode and reduction at air cathode are:

Anode: $\mathrm{Si}+12(\mathrm{HF})_{2} \mathrm{~F}^{-} \leftrightharpoons 8(\mathrm{HF})_{3} \mathrm{~F}^{-} \mathrm{SiF}_{4}+4 \mathrm{e}^{-}$
Cathode: $\mathrm{O}_{2}+12(\mathrm{HF})_{3} \mathrm{~F}^{-}+4 \mathrm{e}^{-} \leftrightharpoons 16(\mathrm{HF})_{2} \mathrm{~F}^{-}+2 \mathrm{H}_{2}$

Crystallization: $\mathrm{SiF}_{4}+2 \mathrm{H}_{2} \mathrm{O}+4(\mathrm{HF})_{2} \mathrm{~F}^{-} \leftrightharpoons \mathrm{SiO}_{2}+4(\mathrm{HF})_{3} \mathrm{~F}^{-}$

Overall Cell Reaction: $\mathrm{Si}+\mathrm{O}_{2} \leftrightharpoons \mathrm{SiO}_{2}$

\subsubsection{Effect of water in the RTIL}

Cohn et al. [100] examined the effect of addition of water in the RTIL electrolyte. It has been concluded that discharge performance of Si-air battery system is greatly obstructed since during cell discharge, the $\mathrm{SiO}_{2}$ precipitates on air cathode's porous carbon. The precipitation of $\mathrm{SiO}_{2}$ layer at a certain point of cell discharge prevents diffusion of oxygen which results into a short supply of oxygen at the electrolyte-electrode interface of air cathode. This results into lowering in discharge capacities of cathode than expected theoretically. Since water plays an important role in the formation of $\mathrm{SiO}_{2}$, it was argued that the formation of $\mathrm{SiO}_{2}$ may shift towards separator or anode by adding water into the electrolyte. If reaction is shifted to take place at the bulk electrolyte rather than at the electrolyte-electrode interface, an alternative location for the $\mathrm{SiO}_{2}$ formation can be introduced causing suffocation to the air-cathode. This is due to the loss of available catalytic sites on the porous surface of the air cathode for oxygen reduction.

The Si-air cells under study are discharged at a constant current density of $0.3 \mathrm{mAh} \mathrm{cm}{ }^{-2}$ and the cut-off potential of $0.5 \mathrm{~V}$. Variation in water content in the electrolyte did not have any affect in open circuit potential (OCP) for the $\mathrm{Si}$-air cell. The dependence of discharge capacity of the $\mathrm{Si}$-air cell is studied as a function of water content of RTIL at a fixed discharge current of $0.3 \mathrm{mAh} \mathrm{cm}^{-2}$. Initially, the discharge capacity increases with water content, reaching a maximum value of $72.5 \mathrm{mAh} \mathrm{cm}^{-2}$ at 15 vol\% of water. On increasing water content beyond $15 \%$, a sharp decrease (up to $40 \%$ ) is observed in the cell discharge capacity up to $80 \%$ water content. Beyond $80 \%$ water content of RTIL, the cell could be operated as it did not display any discharge. From these results, it has been concluded that addition of water in RTIL may be having two opposing effect. One, it facilitates the formation of $\mathrm{SiO}_{2}$ in the bulk electrolyte and not at the air electrode due to which porosity of air electrode remains more or less intact. Second, the activity of RTIL in the electrolyte decreases on increasing the content of water resulting into loss of its distinctive properties of facilitating cathode reaction. With increment in the percentage of water in the electrolyte, the fraction of RTIL in the mixture decreases, and therefore, the unique properties of the RTIL are reduced. 
Fig. 6 Schematic diagram of a silicon-air battery [28, 29]; b A refill-type Si-air cell $[28,29]$
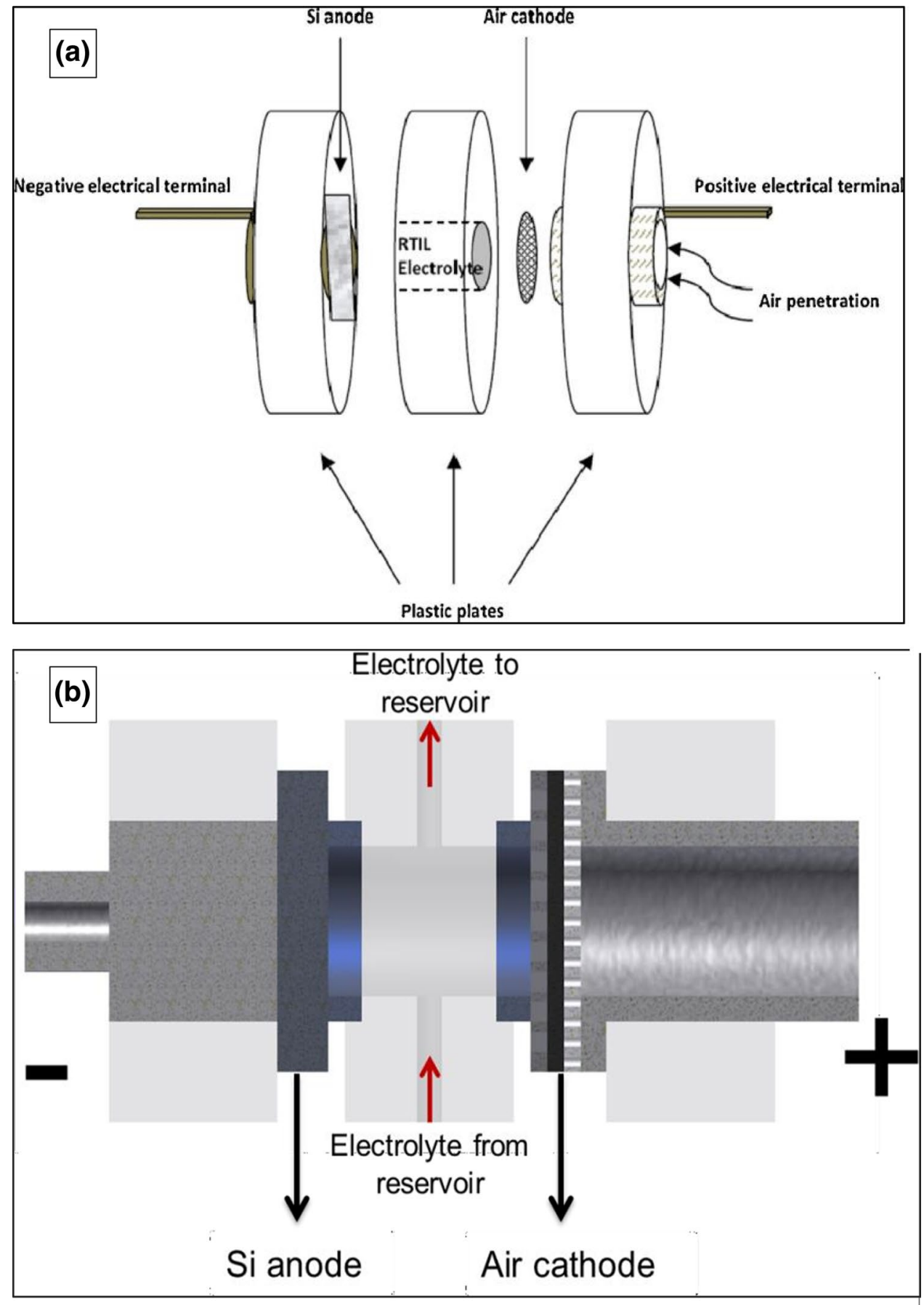

\subsubsection{Gel polymer electrolytes}

Gel polymer electrolytes (GPEs) are formed by integrating a liquid electrolyte into a polymer matrix. Although GPEs are in solid state but the conduction in them is similar to a liquid electrolyte. The use of a gel electrolyte as a moisture barrier eliminates the need to handle liquid electrolyte and simplifies technical issues in cell architecture. Shape flexibility, mechanical stability, high safety and a modest loss in ionic conductivity during discharge process have made
GPEs come into focus as electrolytes. They are commonly used in a variety of applications including Li-lon batteries, solar cells and chemical sensors [101-104].

Yair-Ein-Eli et al. [105] explored the possibility of utilizing a composite polymer electrolyte in $\mathrm{Si}$-air battery system. The gelled polymer electrolyte was derived using specially synthesized EMI.(HF) $)_{2} .3 \mathrm{~F}$ ionic liquid and 2-hydroxyethyl methacrylate (HEMA) as the matrix. The combination of the RTIL and polymer composites are also studied extensively by Tsuda et al. [106]. 
Fig. 7 Polarization voltammograms [19] recorded with RTIL [EMI. $\left.(\mathrm{HF})_{2} \cdot 3 \mathrm{~F}\right]$ at $5 \mathrm{mV} \mathrm{s}^{-1}$ for various electrodes: silicon single-crystal anodes and air cathodes

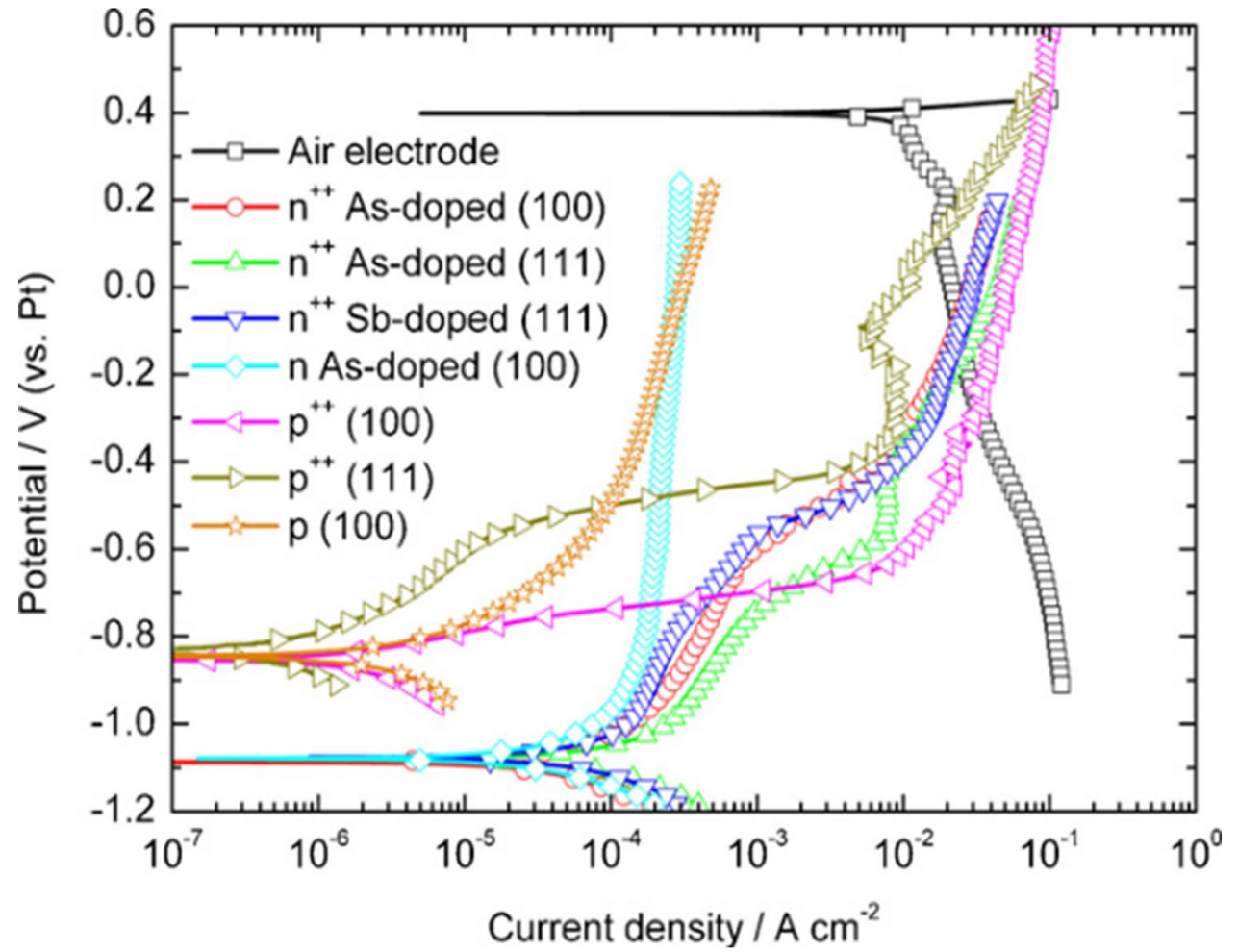

When the battery using GPE of 50-70 mol\% ionic liquid is discharged at a current density of $0.1 \mathrm{~mA} \mathrm{~cm}^{-2}$ in an ambient atmosphere, it's operating potential increases with increasing percentage of RTIL. It is observed that at $50 \mathrm{~mol} \% \mathrm{RTIL}$, it is $0.4 \mathrm{~V}$; at $60 \mathrm{~mol} \%$ it is $0.5 \mathrm{~V}$ and at $70 \mathrm{~mol} \%$ it is $0.6 \mathrm{~V}$ (discharge current was fixed at $0.1 \mathrm{~mA} \mathrm{~cm}^{-2}$ ). When compared with discharge potentials of the cells using pure RTIL, the operating potential of GPEs is $\sim 0.5 \mathrm{~V}$ lower. It has been argued that difference in ionic conductivity of the GPEs is responsible for this variation in operating potential. For instance, it is observed that the ionic conductivity of $60 \mathrm{~mol} \% \mathrm{RTIL}$ is $23 \mathrm{mS} \mathrm{cm}^{-1}$ which is lower than the ionic conductivity of pure RTIL $\left(100 \mathrm{mS} \mathrm{cm}^{-1}\right)$.

Gelled electrolytes comprising of $40-70$ mol\% of EMI. $(\mathrm{HF})_{2} \cdot 3 \mathrm{~F} \mathrm{RTIL}$ and HEMA polymer are found to be free standing and mechanically stable. These GPE can also be well integrated with both Si anode and air cathode. The cell comprising of these electrolytes exhibited a long discharge time of $850 \mathrm{~h}$ at $0.1 \mathrm{~mA} \mathrm{~cm}-2$ operative discharge current density. However, these cells have lower cell voltage when compared with the cells using pure RTIL, and it has been attributed to higher ionic conductivity of the later. Thus, use of GPEs as electrolyte in Si-air battery is feasible for low power devices.

\subsubsection{Corrosion analysis of silicon anode with RTIL electrolyte}

Jakobi et al. [28, 29] studied corrosion mass losses of As-, $\mathrm{Sb}-$, and B-doped $\mathrm{Si}$ anodes at different discharge rates and varying discharge time (up to $20 \mathrm{~h}$ ) (Fig. 8). It was concluded that the electrochemical etching increases surface area significantly along with formation of oxide over layer. The corrosion mass of all types of Si anodes increases with the increase in current density. The electrochemical etching is capable of producing a strong non-porous Si electrode incorporating thick porous layers and tiny pores.

Such $\mathrm{Si}$ anodes shall be favoured in alkaline $\mathrm{Si}$-air batteries due to their enriched discharge behaviour in comparison to flat Si anodes. Further these high surface area nonporous $\mathrm{Si}$ anodes in room temperature ionic liquids are capable of minimizing strong passivation and self-discharge of $\mathrm{Si}$ anodes, enhancing its extended utilization, resulting into development of $\mathrm{Si}$-air batteries having stable voltage profile. The increase in corrosion mass loss for current densities (up to $0.3 \mathrm{~mA} \mathrm{~cm}{ }^{-2}$ ) is found to be linear for $\mathrm{n}$-type $\mathrm{Si}$ anodes. The corrosion mass is significantly lower for $\mathrm{n}$-type $\mathrm{Si}$ anodes with $<111>$ orientation when compared with $<100>$ orientation. Similar trend is found in the As- and Sb-doped Si anodes as well as in p-type Si 

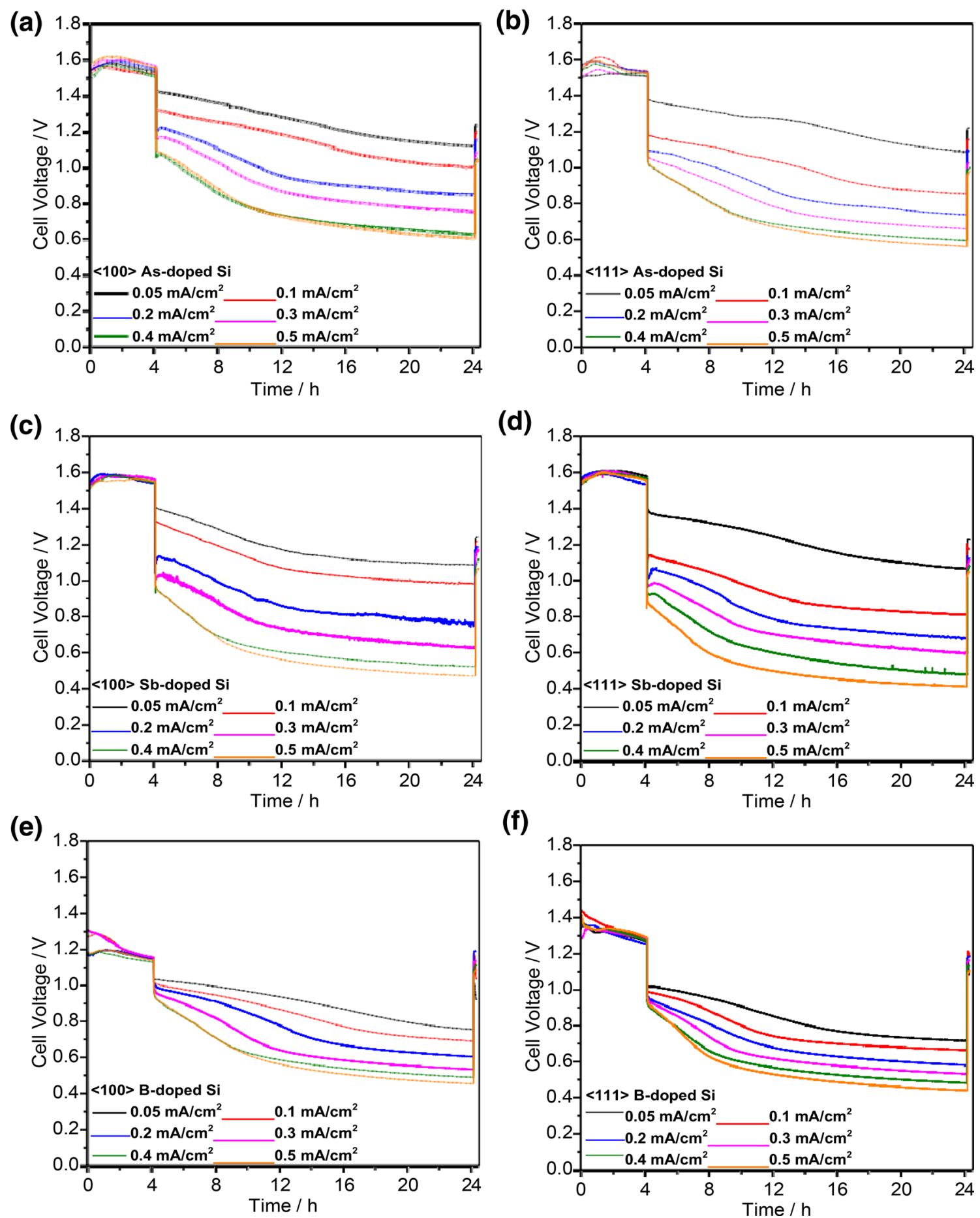

(d)

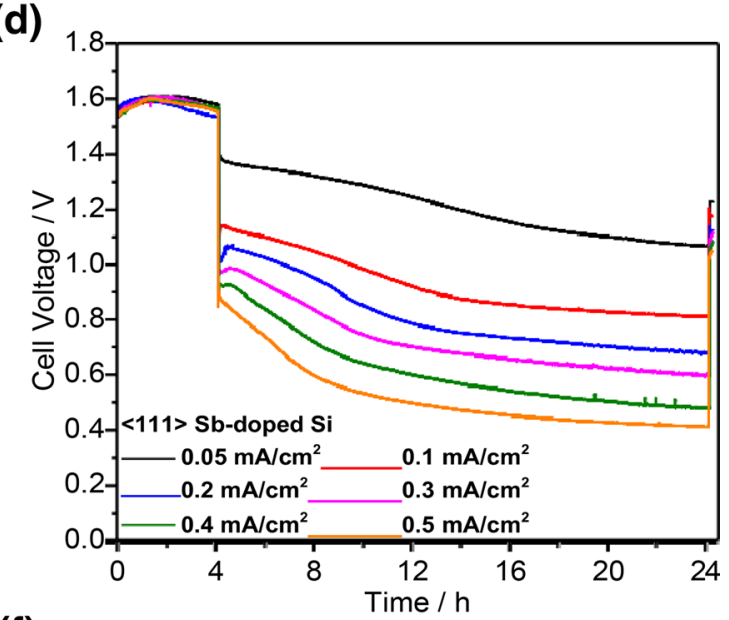

(f)

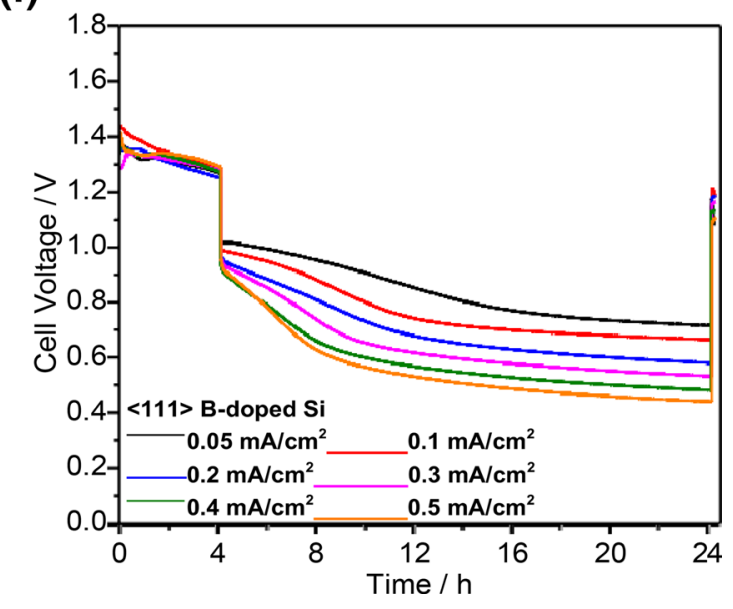

Fig. 8 Influence of dopant type and orientation of silicon anodes on corrosion of Si-air cells for $\mathbf{a}<100>$ oriented As-doped Si anode; b $<111>$ oriented As-doped Si anode; c $<100>$ oriented Sb-doped

Si anode; $\mathbf{d}<111>$ oriented Sb-doped Si anode; e $<100>$ oriented B-doped Si anode; $\mathbf{f}<111>$ oriented B-doped Si anode. Durmus et al. $[28,29]$

anodes to n-type Si anodes. At higher current densities, the corrosion rate is significantly high. Discharge potentials for various dopants at varying current densities are found as detailed below.

(a) For low current densities: $A s_{100}>A s_{111} \approx S b_{100}>S b_{111} \gg$ $B_{100}>B_{111}$

(b) For high current densities: $A s_{100}>A s_{111} \gg S b_{100}>B_{100}$ $>B_{111}>S b_{111}$ 
The anode efficiency, which is dependent on corrosion of an anode, is an essential factor for screening of materials for $\mathrm{Si}$-air batteries. Anode efficiency cannot be $100 \%$; it is a factor that is dependent on the corrosion of the doped anode in the electrolyte. Anode mass conversion efficiency of differently doped Si-anodes for varying current densities are analysed and ranked as: Anodic mass conversion efficiency rankings: $\mathrm{B}_{100} \approx \mathrm{B}_{111} \approx \mathrm{As}_{111}>\mathrm{Sb}_{111} \gg \mathrm{Sb}_{100} \approx \mathrm{As}_{100}$

On the basis of these findings, it has been concluded that $<111>$ oriented As-doped silicon is the first-rate choice as the anode in $\mathrm{Si}$-air batteries, employing $\mathrm{EMI} \cdot(\mathrm{HF})_{2} \cdot 3 \mathrm{~F}$ as the electrolyte.

\subsubsection{Mechanism of discharge termination in silicon-air batteries}

The cell impedance during the discharge process of a Si-Air battery employing RTIL electrolyte has also been investigated [107]. Electrochemical Impedance Spectroscopy (EIS) is utilized to study the generation and development of Si anode and air cathode interfaces in the battery during storage and operation. The effect of exchanging the anode and cathode during discharge and at the end of the discharge is also studied. In order to determine which electrode is contributing to the cell impedance as the most dominant source, it is needed to obtain and analyse the impedance spectra of each electrode. The study of anode impedance exhibited two well-defined semicircles which correspond to high frequency and low frequency regions. The high frequency zone is attributed to space charge layer capacitance and a charge transfer resistance whereas the low frequency zone is attributed to the formation of thin oxide layer on the sub-micron pores during anodic reaction that adds to resistance and capacitance of the cells $[108,109]$. Since the total impedance at the air cathode is considerably lower than the impedance at the anode, it can be neglected. Therefore, the overall cell impedance is originated from the silicon anode impedance.

The role of silicon in the potential drop of the battery during discharge is identified by employing a three-electrode configuration to the $\mathrm{Si}$-air system. The initial drop of the air cathode is larger than the Si anode which can be attributed to dissolved oxygen in the electrolyte that is easily accessible and is consumed in the beginning of the operation but once more and more oxygen is consumed, the over potential of the air cathode increases and the voltage of the air cathode remains unmodified at $0.4 \mathrm{~V}$. On the other hand, the over potential of the Si anode behaves differently. The over potential at electrodes increases with continuous discharge of the battery. The voltage profile of $\mathrm{Si}$-air battery mimics the anode profile which clearly confirms the assumption that $\mathrm{Si}$ anode is the dominant electrode which controls and defines the discharge behaviour
Table 1 Specific capacities of silicon-air batteries

\begin{tabular}{llll}
\hline $\begin{array}{l}\text { Discharge current } \\
\text { density }\left(\mathrm{ma} \mathrm{cm}^{-2}\right)\end{array}$ & $\begin{array}{l}\text { KOH concen- } \\
\text { tration (M) }\end{array}$ & $\begin{array}{l}\text { Mass of } \\
\text { silicon (mg) }\end{array}$ & $\begin{array}{l}\text { Specific } \\
\text { capacity } \\
\left(\mathrm{mAh} \mathrm{g}^{-1}\right)\end{array}$ \\
\hline 0.05 & 6 & 2.26 & 154.8 \\
0.05 & 2 & 1.63 & 214.7 \\
0.05 & 0.6 & 0.49 & 715.7 \\
0.1 & 0.6 & 0.58 & 1206.0 \\
\hline
\end{tabular}

of a Si-air system. Hence, the capacity of the battery is limited by the $\mathrm{Si}$ anode rather than the air cathode.

The importance of the Si-anode with respect to discharge of $\mathrm{Si}$-air battery is investigated by replacing the anode electrode during the discharge as well as at the end of the discharge. When the anode is replaced during the middle of the discharge, there is no effect on the discharge voltage. However, the discharge capacity almost doubles at the end of the operation of the second silicon anode. With each changing period, the capacity decreases to such an extent that after the fifth replacement, the increase in the discharge capacity is negligible as compared to previous exchanges. The reason why the fifth replacement does not give a significant increase on discharge capacity is because of the degradation of the air cathode and the electrolyte during the discharge process.

\subsection{Alkaline electrolyte}

A primary Si-Air battery employing nanostructured silicon as anode material with an alkaline solution based electrolyte was investigated by Zhong et al. [23]. Typical galvanostatic discharge of the cell exhibited that the cell can be used to draw current at $0.05 \mathrm{~mA} \mathrm{~cm}^{-2}$ over a period of $30 \mathrm{~h}$ at an operating potential of $1.2 \mathrm{~V}$. In contrast, in a control experiment using an unmodified silicon wafer, the cell is completely discharged in less than $10 \mathrm{~min}$ at a potential of $1.1 \mathrm{~V}$ i.e. the potential quickly drops to zero. The electrode reactions are:

Anode: $\mathrm{Si}+4 \mathrm{OH}^{-} \leftrightharpoons \mathrm{Si}(\mathrm{OH})_{4}+4 \mathrm{e}^{-} \mathrm{E}_{\mathrm{o}}=1.69 \mathrm{~V}$

Cathode: $\mathrm{O}_{2}+2 \mathrm{H}_{2} \mathrm{O}+4 \mathrm{e}^{-} \leftrightharpoons 4 \mathrm{OH}^{-} \mathrm{E}_{\mathrm{o}}=0.40 \mathrm{~V}$

The main benefit of employing an alkaline solution is its ability to dissolve $\mathrm{Si}(\mathrm{OH})_{4}$. The surface can be covered by silicon oxide if the dissolution rate of $\mathrm{Si}(\mathrm{OH})_{4}$ is not fast enough. The formation of a porous surface structure increases the dissolution rate of $\mathrm{Si}(\mathrm{OH})_{4}$ in the $\mathrm{KOH}$ electrolyte. This facilitates the effective removal of the oxide and reactivates the Si-surface. On the other hand, the 
unmodified silicon surface become passive very quickly and results in a very short discharge time.

Various concentrations of the alkaline solution as electrolyte are studied. It is reported that the self-discharge rate is highly dependent on the electrolyte composition. It is observed that anodic dissolution potential is directly proportional to $\mathrm{KOH}$ concentrations (Table 1).

\subsubsection{Corrosion analysis of silicon anode with alkaline electrolyte}

Durmus et al. [110] studied the corrosion of As-doped $(0.001-0.007 \mu \mathrm{cm})$ crystalline Si wafers in $0.5-12 \mathrm{M} \mathrm{KOH}$ solution. It is concluded that the chemical corrosion of $\mathrm{Si}$ is a surface reaction limited process. While in $0.3-5 \mathrm{M}$ $\mathrm{KOH}$, anisotropic etching leads to very rough surfaces and pyramidal hillocks, smoother surfaces at $>5 \mathrm{M} \mathrm{KOH}$ is attributed to polishing process. Hence, the anodic oxidation of As-doped Si does not depend on strength of $\mathrm{KOH}$. Durmus et al. proposed that the electron transfer is the rate determining step of corrosion of As-doped Si using galvanostatic discharge data. They further suggested that the focus on the corrosion inhibition will help in improving the shelf-life and discharge performance of the primary $\mathrm{Si}$-air batteries. It can be concluded that weak $\mathrm{KOH}$ enhances the shelf life while strong $\mathrm{KOH}$ will ensure continuous discharge at high current densities. The effect of $\mathrm{KOH}$ concentration on the corrosion rates of As-doped $\mathrm{Si}$ anodes can be understood by considering the following reaction mechanism:

$\mathrm{Si}+2 \mathrm{OH}^{-}+2 \mathrm{H}_{2} \mathrm{O} \leftrightharpoons \mathrm{SiO}_{2}(\mathrm{OH})_{2}^{2-}+2 \mathrm{H}_{2}$

At $15^{\circ} \mathrm{C}$, Si undergoes corrosion @ $0.66 \mu \mathrm{m} \mathrm{h}^{-1}$, which increases to $1.46 \mu \mathrm{m} \mathrm{h}^{-1}$ at $25^{\circ} \mathrm{C}$. Further increase in temperature showed exponential increase of the corrosion rates, observed to be $13.62 \mu \mathrm{m} \mathrm{h}^{-1}$ at $60^{\circ} \mathrm{C}$. This behaviour is in accordance with Arrhenius equation which states that etching rate increases with temperature.

The variation of $\mathrm{KOH}$ changes the relative concentration of $\mathrm{OH}^{-}$and $\mathrm{H}_{2} \mathrm{O}$ in the solutions, which results in a change in their activities. In case of hydroxide ions, the activity increases almost linearly beginning from $1 \mathrm{M}$ of $\mathrm{KOH}$ whereas $\mathrm{KOH}$ activity decreases [111-113].

\section{Conclusion and outlook}

This mini review is an effort to summarise recent developments of Si-anode, air cathode, different electrolytes and their effect on the discharge mechanisms and working potentials in a $\mathrm{Si}$-air battery system. Despite the intense research, there is still much scope for further advancement of this novel type of $\mathrm{Si}$-air technology. Prospective directions for future research in Silicon-air batteries could focus on the following:

1. Pure silicon wafers are the most common material for $\mathrm{Si}$ anode but the drawback is their high corrosion rates. It is required to find a $\mathrm{Si}$ anode that is capable to sustain its capacity over hundreds of discharge and charge cycles. Therefore, nano-structured silicon and doped silicon can be used to improve the performance of the Si anode. Structural modifications such as electro deposition or chemical modification by the means of additives has proven to be an ideal solution to find such an anode material. The additives must be effective in small quantities since a large amount of additive can reduce the overall capacity of the silicon material. More studies are needed to properly understand the charge and discharge mechanisms for the optimisation of the discharge time. A more effective methodology is needed to find solution for corrosion or passivation in $\mathrm{Si}$-air battery.

2. The air cathode is an essential part of any type of metal-air battery but its kinetics of the oxygen reduction reaction hinders its performance. Therefore, electro catalysts play an important role in the cathode. Noble metals such as Pt and Pt-alloy based catalysts have been extensively used as electro catalysts in air electrode. To further reduce the cost, different type of catalysts such as high spin transition metal complexes and inorganic-organic composites can be used as a highly efficient alternative. It has been observed that the specific capacity of an air electrode depends on various factors. Thus, a suitable choice for an air electrode would be to choose a very thin and highly porous graphite nano-sheet with optimal pore size which is impregnated with an appropriate electro catalyst. Further development of low cost catalysts with improved activity and durability is necessary to improve the sluggish kinetics of air electrode. One such example of an electro catalyst could be inexpensive bi-functional catalysts which is active to both oxygen evolution reaction and oxygen reduction reaction.

3. New highly stable electrolyte technologies that allow long-lasting operation of $\mathrm{Si}$-air batteries are required for further advancement. At present, lonic liquids are the most promising electrolytes for $\mathrm{Si}$-Air batteries. Thermally and mechanically stable gel polymer electrolyte appears to be a viable candidate as electrolyte for future research. Solidification of the electrolyte system is important to maintain the safe operation \& easy handling of the battery and structural integrity under various deformations. It is also highly important 
to study the properties at the electrode-electrolyte interface of the battery.

4. Simulations are needed in order to provide an optimal design of Si-air batteries in terms of structural design of anode and cathode, as well as dispersion of electrolyte, electro catalyst, current collector and depolarizers in order to provide a corrosion-free contact between the electrodes and electrolyte. Moreover, the understanding of silicon dendritic growth in $\mathrm{Si}$-air batteries is still in its infancy. Although there are many challenges faced, it is worth applying efforts to develop $\mathrm{Si}$-air batteries for next-generation energy storage technology.

\section{Compliance with ethical standards}

Conflict of interest The authors declare that they have no conflict of interest.

\section{References}

1. Zhang X, Wang XG, Xie Z, Zhou Z (2018) Recent progress in rechargeable alkali metal-air batteries. Green Energy Environ 1(1):4-17

2. Fu J, Cano ZP, Park MG, Yu A, Fowler M, Chen Z (2018) Electrically rechargeable zinc-air batteries: progress, challenges, and perspectives. Adv Mater 29(7):1604685

3. Rinaldi A, Wang Y, Tan KS, Wijaya O, Yazami R (2015) Lithiumair batteries for medium- and large-scale energy storage. In: Advances in batteries for medium and large-scale energy storage. pp 387-440

4. Zhang T, Tao Z, Chen J (2014) Magnesium-air batteries: from principle to application. Mater Horiz 1(2):196-206

5. Li Y, Lu J (2017) Metal-air batteries: will they be the future electrochemical energy storage device of choice? ACS Energy Lett 2(6):1370-1377

6. Hamlen RP, Hoge WH, Hunter JA, O'Callaghan WB (1991) Applications of aluminum-air batteries. IEEE Aerosp Electron Syst Mag 6(10):11-14

7. Peng H, XuY, Pan J, Zhao Y, Wang L, Shi X (2018) Flexible metalair batteries: fundamentals and applications. In: Metal-Air Batteries. pp 367-396

8. Das SK, Lau S, Archer LA (2014) Sodium-oxygen batteries: a new class of metal-air batteries. J Mater Chem A 2(32):12623

9. Blurton KF, Sammells AF (1979) Metal/air batteries: their status and potential: a review. J Power Sources 4(4):263-279

10. Girishkumar G, McCloskey B, Luntz AC, Swanson S, Wilcke W (2010) Lithium-air battery: promise and challenges. J Phys Chem Lett 1(14):2193-2203

11. Kraytsberg A, Ein-Eli Y (2011) Review on Li-air batteriesopportunities, limitations and perspective. J Power Sources 196(3):886-893

12. Lee JS, Tai Kim S, Cao R, Choi NS, Liu M, Lee KT, Cho J (2010) Metal-air batteries with high energy density: $\mathrm{Li}$-air versus $\mathrm{Zn}-$ air. Adv Energy Mater 1(1):34-50

13. Wang T, Kaempgen M, Nopphawan P, Wee G, Mhaisalkar S, Srinivasan M (2010) Silver nanoparticle-decorated carbon nanotubes as bifunctional gas-diffusion electrodes for zincair batteries. J Power Sources 195(13):4350-4355. https://doi. org/10.1016/j.jpowsour.2009.12.137

14. Li CS, Sun Y, Gebert F, Chou SL (2017) Current progress on rechargeable magnesium-air battery. Adv Energy Mater 7(24):1700869

15. Mohamad AA, Mohamed NS, Alias Y, Arof AK (2003) Mechanically alloyed $\mathrm{Mg} 2 \mathrm{Ni}$ for metal-hydride-air secondary battery. J Power Sources 115(1):161-166

16. Durmus YE (2018) Investigation and development of a resource efficient metal-air battery: silicon-air. M.Sc. disssertation, RWTH Aachen University, Germany

17. Cohn G, Starosvetsky D, Hagiwara R, Macdonald DD, EinEli $Y$ (2009) Silicon-air batteries. Electrochem Commun 11(10):1916-1918

18. Jakes $P$, Cohn $G$, Ein-Eli $Y$, Scheiba F, Ehrenberg H, Eichel RA (2012) Limitation of discharge capacity and mechanisms of airelectrode deactivation in silicon-air batteries. Chemsuschem 5(11):2278-2285

19. Cohn G, Ein-Eli Y (2010) Study and development of non-aqueous silicon-air battery. J Power Sources 195(15):4963-4970

20. Teki R, Datta MK, Krishnan R, Parker TC, Lu TM, Kumta PN, Koratkar N (2009) Nanostructured silicon anodes for lithium ion rechargeable batteries. Small 5(20):2236-2242

21. Szczech JR, Jin S (2011) Nanostructured silicon for high capacity lithium battery anodes. Energy Environ Sci 4(1):56-72

22. Ge M, Rong J, Fang X, Zhou C (2012) Porous doped silicon nanowires for lithium ion battery anode with long cycle life. Nano Lett 12(5):2318-2323

23. Zhong X, Zhang H, Liu Y, Bai J, Liao L, Huang Y, Duan X (2011) High-capacity silicon-air battery in alkaline solution. Chem Sus Chem 5(1):177-180

24. Zhong X, Qu Y, Lin YC, Liao L, Duan X (2011) Unveiling the formation pathway of single crystalline porous silicon nanowires. ACS Appl Mater Interfaces 3(2):261-270

25. Xue M, Zhong X, Shaposhnik Z, Qu Y, Tamanoi F, Duan X, Zink JI (2011) pH-operated mechanized porous silicon nanoparticles. J Am Chem Soc 133(23):8798-8801

26. Qu Y, Liao L, Li Y, Zhang H, Huang Y, Duan X (2009) Electrically conductive and optically active porous silicon nanowires. Nano Lett 9(12):4539-4543

27. Qu Y, Zhong X, Li Y, Liao L, Huang Y, Duan X (2010) Photocatalytic properties of porous silicon nanowires. J Mater Chem 20(18):3590

28. Durmus YE, Jakobi S, Beuse T, Aslanbas Ö, Tempel H, Hausen F, Kungl H (2017) Influence of dopant type and orientation of silicon anodes on performance, efficiency and corrosion of silicon-air cells with EMIm(HF)2.3F electrolyte. J Electrochem Soc 164(12):A2310-A2320

29. Durmus YE (2018) Investigation and development of a resource efficient metal-air battery: silicon-air, M.S. dissertation

30. Cheng H, Scott K (2010) Carbon-supported manganese oxide nanocatalysts for rechargeable lithium-air batteries. J Power Sources 195(5):1370-1374

31. Xiao J, Wang D, Xu W, Wang D, Williford RE, Liu J, Zhang JG (2010) Optimization of air electrode for li/air batteries. J Electrochem Soc 157(4):A487

32. Yang X, He P, Xia Y (2009) Preparation of mesocellular carbon foam and its application for lithium/oxygen battery. Electrochem Commun 11(6):1127-1130

33. Zhang GQ, Zheng JP, Liang R, Zhang C, Wang B, Hendrickson $M$, Plichta EJ (2010) Lithium-Air Batteries Using SWNT/CNF Buckypapers as Air Electrodes. J Electrochem Soc 157(8):A953

34. Beattie SD, Manolescu DM, Blair SL (2009) High-capacity lithium-air cathodes. J Electrochem Soc 156(1):A44 
35. Read J, Mutolo K, Ervin M, Behl W, Wolfenstine J, Driedger A, Foster D (2003) Oxygen transport properties of organic electrolytes and performance of lithium/oxygen battery. J Electrochem Soc 150(10):A1351

36. Yang X, Xia Y (2009) The effect of oxygen pressures on the electrochemical profile of lithium/oxygen battery. J Solid State Electrochem 14(1):109-114

37. Tran C, Yang XQ, Qu D (2010) Investigation of the gas-diffusionelectrode used as lithium/air cathode in non-aqueous electrolyte and the importance of carbon material porosity. J Power Sources 195(7):2057-2063

38. Yamamoto K, Imaoka T, Chun WJ, Enoki O, Katoh H, Takenaga M, Sonoi A (2009) Size-specific catalytic activity of platinum clusters enhances oxygen reduction reactions. Nat Chem 1(5):397-402

39. Lim B, Jiang M, Camargo PHC, Cho EC, Tao J, Lu X, Xia Y (2009) $\mathrm{Pd}-\mathrm{Pt}$ bimetallic nanodendrites with high activity for oxygen reduction. Science 324(5932):1302-1305

40. Zhou ZY, Tian N, Li JT, Broadwell I, Sun SG (2011) Nanomaterials of high surface energy with exceptional properties in catalysis and energy storage. Chem Soc Rev 40(7):4167

41. Bing Y, Liu H, Zhang L, Ghosh D, Zhang J (2010) Nanostructured Pt-alloy electrocatalysts for PEM fuel cell oxygen reduction reaction. Chem Soc Rev 39(6):2184

42. Stamenkovic VR, Fowler B, Mun BS, Wang G, Ross PN, Lucas CA, Markovic NM (2007) Improved oxygen reduction activity on Pt3Ni(111) via increased surface site availability. Science 315(5811):493-497

43. Stamenkovic VR, Mun BS, Arenz M, Mayrhofer KJJ, Lucas CA, Wang G, Markovic NM (2007) Trends in electrocatalysis on extended and nanoscale Pt-bimetallic alloy surfaces. Nat Mater 6(3):241-247

44. Greeley J, Stephens IEL, Bondarenko AS, Johansson TP, Hansen HA, Jaramillo TF, Nørskov JK (2009) Alloys of platinum and early transition metals as oxygen reduction electrocatalysts. Nat Chem 1(7):552-556

45. Strasser P, Koh S, Anniyev T, Greeley J, More K, Yu C, Nilsson A (2010) Lattice-strain control of the activity in dealloyed coreshell fuel cell catalysts. Nat Chem 2(6):454-460

46. Kim J, Lee Y, Sun S (2010) Structurally ordered FePt nanoparticles and their enhanced catalysis for oxygen reduction reaction. J Am Chem Soc 132(14):4996-4997

47. Jong Yoo S, Kim SK, Jeon TY, Jun Hwang S, Lee JG, Lee SC, Lim TH (2011) Enhanced stability and activity of Pt-Y alloy catalysts for electrocatalytic oxygen reduction. Chem Commun 47(41):11414

48. Šljukić B, Banks CE, Mentus S, Compton RG (2004) Modification of carbon electrodes for oxygen reduction and hydrogen peroxide formation: the search for stable and efficient sonoelectrocatalysts. Phys Chem Chem Phys 6(5):992-997

49. Shao Y, Liu J, Wang Y, Lin Y (2009) Novel catalyst support materials for PEMfuelcells: current status and future prospects. J Mater Chem 19(1):46-59

50. Banham D, Feng F, Fürstenhaupt T, Pei K, Ye S, Birss V (2011) Effect of Pt-loaded carbon support nanostructure on oxygen reduction catalysis. J Power Sources 196(13):5438-5445

51. Bao X, Von Deak D, Biddinger EJ, Ozkan US, Hadad CM (2010) A computational exploration of the oxygen reduction reaction over a carbon catalyst containing a phosphinate functional group. Chem Commun 46(45):8621

52. Von Deak D, Biddinger EJ, Ozkan US (2011) Carbon corrosion characteristics of CNx nanostructures in acidic media and implications for ORR performance. J Appl Electrochem 41(7):757-763

53. Zhou Y, Neyerlin K, Olson TS, Pylypenko S, Bult J, Dinh HN, O'Hayre R (2010) Enhancement of Pt and Pt-alloy fuel cell catalyst activity and durability via nitrogen-modified carbon supports. Energy Environ Sci 3(10):1437. https://doi. org/10.1039/c003710a

54. Pylypenko S, Queen A, Olson TS, Dameron A, O'Neill K, Neyerlin KC, O'Hayre R (2011) Tuning carbon-based fuel cell catalyst support structures via nitrogen functionalization. I. investigation of structural and compositional modification of highly oriented pyrolytic graphite model catalyst supports as a function of nitrogen implantation dose. J Phys Chem C 115(28):1366713675. https://doi.org/10.1021/jp1122344

55. Oh H-S, Oh J-G, Lee WH, Kim H-J, Kim H (2011) The influence of the structural properties of carbon on the oxygen reduction reaction of nitrogen modified carbon based catalysts. Int J Hydrog Energy 36(14):8181-8186. https://doi.org/10.1016/j. ijhydene.2011.04.139

56. Liu S-H, Wu M-T, Lai Y-H, Chiang C-C, Yu N, Liu S-B (2011) Fabrication and electrocatalytic performance of highly stable and active platinum nanoparticles supported on nitrogen-doped ordered mesoporous carbons for oxygen reduction reaction. J Mater Chem 21(33):12489. https://doi.org/10.1039/c1jm1 $1488 \mathrm{c}$

57. Liang C, Ding L, Li C, Pang M, Su D, Li W, Wang Y (2010) Nanostructured WCX/CNTs as highly efficient support of electrocatalysts with low Pt loading for oxygen reduction reaction. Energy Environ Sci 3(8):1121. https://doi.org/10.1039/c001423k

58. Shao M, Merzougui B, Shoemaker K, Stolar L, Protsailo L, Mellinger ZJ, Chen JG (2011) Tungsten carbide modified high surface area carbon as fuel cell catalyst support. J Power Sources 196(18):7426-7434. https://doi.org/10.1016/j.jpows our.2011.04.026

59. Zhang W, Sherrell P, Minett Al, Razal JM, Chen J (2010) Carbon nanotube architectures as catalyst supports for proton exchange membrane fuel cells. Energy Environ Sci 3(9):1286. https://doi.org/10.1039/c0ee00139b

60. Yuan Y, Smith JA, Goenaga G, Liu D-J, Luo Z, Liu J (2011) Platinum decorated aligned carbon nanotubes: electrocatalyst for improved performance of proton exchange membrane fuel cells. J Power Sources 196(15):6160-6167. https://doi. org/10.1016/j.jpowsour.2011.03.026

61. Zhang S, Shao Y, Yin G, Lin Y (2010) Carbon nanotubes decorated with Pt nanoparticles via electrostatic self-assembly: a highly active oxygen reduction electrocatalyst. J Mater Chem 20(14):2826. https://doi.org/10.1039/b919494k

62. Zhang Y, Hu Y, Li S, Sun J, Hou B (2011) Manganese dioxidecoated carbon nanotubes as an improved cathodic catalyst for oxygen reduction in a microbial fuel cell. J Power Sources 196(22):9284-9289. https://doi.org/10.1016/j.jpows our.2011.07.069

63. Fujigaya T, Uchinoumi T, Kaneko K, Nakashima N (2011) Design and synthesis of nitrogen-containing calcined polymer/carbon nanotube hybrids that act as a platinum-free oxygen reduction fuel cell catalyst. Chem Commun 47(24):6843. https://doi. org/10.1039/c1cc11303h

64. Geng D, Chen Y, Chen Y, Li Y, Li R, Sun X, Knights S (2011) High oxygen-reduction activity and durability of nitrogen-doped graphene. Energy Environ Sci 4(3):760. https://doi.org/10.1039/ c0ee00326c

65. Hayden BE, Pletcher D, Suchsland J-P, Williams LJ (2009) The influence of support and particle size on the platinum catalysed oxygen reduction reaction. Phys Chem Chem Phys 11(40):9141. https://doi.org/10.1039/b910110a

66. Wu G, Nelson MA, Mack NH, Ma S, Sekhar P, Garzon FH, Zelenay $P$ (2010) Titanium dioxide-supported non-precious metal oxygen reduction electrocatalyst. Chem Commun 46(40):7489. https://doi.org/10.1039/c0cc03088k 
67. Ho VTT, Pan C-J, Rick J, Su W-N, Hwang B-J (2011) Nanostructured Ti0.7 Mo0. $3 \mathrm{O}_{2}$ support enhances electron transfer to pt: high-performance catalyst for oxygen reduction reaction. J Am Chem Soc 133(30):11716-11724. https://doi.org/10.1021/ja203 9562

68. Chen J, Takanabe K, Ohnishi R, Lu D, Okada S, Hatasawa H, Domen K (2010) Nano-sized TiN on carbon black as an efficient electrocatalyst for the oxygen reduction reaction prepared using an mpg-C3N4 template. Chem Commun 46(40):7492. https://doi.org/10.1039/c0cc02048f

69. Hu Z, Chen C, Meng H, Wang R, Shen PK, Fu H (2011) Oxygen reduction electrocatalysis enhanced by nanosized cubic vanadium carbide. Electrochem Commun 13(8):763-765. https:// doi.org/10.1016/j.elecom.2011.03.004

70. Yin S, Cai M, Wang C, Shen PK (2011) Tungsten carbide promoted Pd-Fe as alcohol-tolerant electrocatalysts for oxygen reduction reactions. Energy Environ Sci 4(2):558-563. https:// doi.org/10.1039/c0ee00445f

71. Post JE (1990) Manganese oxide minerals: crystal structures and economic and environmental significance. Proc Natl Acad Sci 96(7):3447-3454. https://doi.org/10.1073/pnas.96.7.3447

72. Mathur A, Halder A (2019) One step synthesis of bifunctional iron doped manganese oxide nanorods for rechargeable zinc air battery. Catal Sci Technol. https://doi.org/10.1039/c8cy0 $2498 \mathrm{~g}$

73. Roche I, Chaînet E, Chatenet M, Vondrák J (2006) Carbon-supported manganese oxide nanoparticles as electrocatalysts for the oxygen reduction reaction (ORR) in alkaline medium: physical characterizations and ORR mechanism. J Phys Chem C 111(3):1434-1443. https://doi.org/10.1021/jp0647986

74. Cheng F, Shen J, Ji W, Tao Z, Chen J (2009) Selective synthesis of manganese oxide nanostructures for electrocatalytic oxygen reduction. ACS Appl Mater Interfaces 1(2):460-466. https://doi. org/10.1021/am800131v

75. Lima FHB, Calegaro ML, Ticianelli EA (2007) Electrocatalytic activity of manganese oxides prepared by thermal decomposition for oxygen reduction. Electrochim Acta 52(11):3732-3738. https://doi.org/10.1016/j.electacta.2006.10.047

76. Jaouen $F$, Proietti $E$, Lefèvre $M$, Chenitz $R$, Dodelet J-P, Wu G, Zelenay $P$ (2011) Recent advances in non-precious metal catalysis for oxygen-reduction reaction in polymer electrolyte fuelcells. Energy Environ Sci 4(1):114-130. https://doi.org/10.1039/ c0ee00011f

77. Chen Z, Higgins D, Yu A, Zhang L, Zhang J (2011) A review on non-precious metal electrocatalysts for PEM fuel cells. Energy Environ Sci 4(9):3167. https://doi.org/10.1039/c0ee00558d

78. Bezerra CWB, Zhang L, Lee K, Liu H, Marques ALB, Marques EP, Zhang J (2008) A review of Fe-N/C and Co-N/C catalysts for the oxygen reduction reaction. Electrochim Acta 53(15):49374951. https://doi.org/10.1016/j.electacta.2008.02.012

79. Easton EB, Yang R, Bonakdarpour A, Dahn JR (2007) Thermal evolution of the structure and activity of magnetron-sputtered $\mathrm{TM}-\mathrm{C}-\mathrm{N}(\mathrm{TM}=\mathrm{Fe}, \mathrm{Co})$ oxygen reduction catalysts. Electrochem Solid-State Lett 10(1):B6-B10. https://doi.org/10.1149/1.23639 47

80. Easton EB, Bonakdarpour A, Yang R, Stevens DA, Dahn JR (2008) Magnetron sputtered Fe-C-N, Fe-C, and $\mathrm{C}-\mathrm{N}$ based oxygen reduction electrocatalysts. J Electrochem Soc 155(6):B547. https://doi.org/10.1149/1.2899013

81. He Q, Yang X, Ren X, Koel BE, Ramaswamy N, Mukerjee S, Kostecki R (2011) A novel CuFe-based catalyst for the oxygen reduction reaction in alkaline media. J Power Sources 196(18):7404-7410. https://doi.org/10.1016/j.jpows our.2011.04.016

82. Winther-Jensen B, Winther-Jensen O, Forsyth M, MacFarlane DR (2008) High rates of oxygen reduction over a vapor phase-polymerized PEDOT electrode. Science 321(5889):671674. https://doi.org/10.1126/science.1159267

83. Trojánek A, Langmaier J, Šebera J, Záliš S, Barbe J-M, Girault HH, Samec $Z$ (2011) Fine tuning of the catalytic effect of a metalfree porphyrin on the homogeneous oxygen reduction. Chem Commun 47(19):5446. https://doi.org/10.1039/c1cc11075f

84. Chen J, Zhang W, Officer D, Swiegers GF, Wallace GG (2007) A readily-prepared, convergent, oxygen reduction electrocatalyst. Chem Commun 32:3353. https://doi.org/10.1039/b7077 $99 \mathrm{~h}$

85. Wu G, More KL, Johnston CM, Zelenay P (2011) High-performance electrocatalysts for oxygen reduction derived from polyaniline, iron, and cobalt. Science 332(6028):443-447. https ://doi.org/10.1126/science.1200832

86. Bashyam R, Zelenay P (2006) A class of non-precious metal composite catalysts for fuel cells. Nature 443(7107):63-66. https://doi.org/10.1038/nature05118

87. Lee S, Zhu S, Milleville CC, Lee C-Y, Chen P, Takeuchi KJ, Marschilok AC (2010) Metal-air electrochemical cells: silver-polymer-carbon composite air electrodes. Electrochem Solid State Lett 13(11):A162. https://doi.org/10.1149/1.3479660

88. Chen Z, Choi J-Y, Wang H, Li H, Chen Z (2011) Highly durable and active non-precious air cathode catalyst for zinc air battery. J Power Sources 196(7):3673-3677. https://doi.org/10.1016/j. jpowsour.2010.12.047

89. Gong KP, Du F, Xia ZH, Durstock M, Dai LM (2009) Nitrogendoped carbon nanotube arrays with high electrocatalytic activity for oxygen reduction. Science 323:760-764

90. Shui J, Karan NK, Balasubramanian M, Li SY, Liu DJ (2012) Fe/N/C composite in $\mathrm{Li}-\mathrm{O}_{2}$ battery: studies of catalytic structure and activity toward oxygen evolution reaction. J Am Chem Soc 134:16654-16661

91. Shui J, Wang M, Du F, Dai L (2015) N-doped carbon nanomaterials are durable catalysts for oxygen reduction reaction in acidic fuel cells. Sci Adv 1(1):e1400129

92. Choi CH, Chung MW, Kwon HC, Park SH, Woo S (2013) B, Nand $\mathrm{P}, \mathrm{N}$-doped graphene as highly active catalysts for oxygen reduction reactions in acidic medi. J Mater Chem A 1:36943699. https://doi.org/10.1039/C3TA01648J

93. Choi CH, Park SH, Woo S (2012) Phosphorus-nitrogen dual doped carbon as an effective catalyst for oxygen reduction reaction in acidic media: effects of the amount of P-doping on the physical and electrochemical properties of carbon. J Mater Chem 22:12107. https://doi.org/10.1039/c2jm31079a

94. Zhang S, Cai Y, He H, Zhang Y, Liu R, Cao H, Wang M, Liu J, Zhang G, Li Y, Liu H, Li B (2016) Heteroatom doped graphdiyne as efficient metal-free electrocatalyst for oxygen reduction reaction in alkaline medium. J Mater Chem A 4:4738-4744. https://doi. org/10.1039/c5ta10579j

95. Zhang J, Dai L (2015) Heteroatom-doped graphitic carbon catalysts for efficient electrocatalyst of oxygen reduction reaction. ACS Catal 5(12):7244-7253. https://doi.org/10.1021/acsca tal.5b01563

96. Choi CH, Park SH, Woo S (2011) Heteroatom doped carbons prepared by the pyrolysis of bio-derived amino acids as highly active catalysts for oxygen electro-reduction reactions. Green Chem 13:406-412

97. Hagiwara R, Hirashige T, Tsuda T, Ito Y (2002) A highly conductive room temperature molten fluoride: EMIF 2.3HF. J Electrochem Soc 149(1):D1. https://doi.org/10.1149/1.1421606

98. Matsumoto K, Hagiwara R, Yoshida R, Ito Y, Mazej Z, Benkič P, Matsubara S (2004) Syntheses, structures and properties of 1-ethyl-3-methylimidazolium salts of fluorocomplex anions. Dalton Trans 1:144-149. https://doi.org/10.1039/b310162b

99. Hagiwara R, Nakamori Y, Matsumoto K, Ito Y (2005) The effect of the anion fraction on the physicochemical properties of 
EMIm(HF)nF ( $n=1.0-2.6)$. J Phys Chem B 109(12):5445-5449. https://doi.org/10.1021/jp047006l

100. Cohn G, Macdonald DD, Ein-Eli Y (2011) Remarkable impact of water on the discharge performance of a silicon-air battery. ChemSusChem 4(8):1124-1129. https://doi.org/10.1002/ cssc.201100169

101. Long $L$, Wang S, Xiao M, Meng Y (2016) Polymer electrolytes for lithium polymer batteries. J Mater Chem A 4(26):10038-10069. https://doi.org/10.1039/c6ta02621d

102. Wang Y (2009) Recent research progress on polymer electrolytes for dye-sensitized solar cells. Solar Energy Mater Solar Cells 93(8):1167-1175. https://doi.org/10.1016/j.solma t.2009.01.009

103. Fergus JW (2010) Ceramic and polymeric solid electrolytes for lithium-ion batteries. J Power Sources 195(15):4554-4569. https://doi.org/10.1016/j.jpowsour.2010.01.076

104. Zewde BW, Carbone L, Greenbaum S, Hassoun J (2018) A novel polymer electrolyte membrane for application in solid state lithium metal battery. Solid State lonics 317:97-102. https:// doi.org/10.1016/j.ssi.2017.12.039

105. Cohn G, Altberg A, Macdonald DD, Ein-Eli Y (2011) A siliconair battery utilizing a composite polymer electrolyte. ElectrochimicaActa 58:161-164. https://doi.org/10.1016/j.elect acta.2011.09.026

106. Tsuda T (2002) A highly conductive composite electrolyte consisting of polymer and room temperature molten fluorohydrogenates. Solid State lonics 149(3-4):295-298. https://doi. org/10.1016/s0167-2738(02)00399-5

107. Cohn G, Eichel RA, Ein-Eli Y (2013) New insight into the discharge mechanism of silicon-air batteries using electrochemical impedance spectroscopy. Phys Chem Chem Phys 15(9):3256. https://doi.org/10.1039/c2cp43870d

108. Raz O, Shmueli Z, Hagiwara R, Ein-Eli Y (2010) Porous silicon formation in fluorohydrogenate ionic liquids. J Electrochem Soc 157(3):H281. https://doi.org/10.1149/1.3273082

109. Raz O, Starosvetsky D, Tsuda T, Nohira T, Hagiwara R, Ein-Eli Y (2007) Macroporous silicon formation on n-si in room-temperature fluorohydrogenate ionic liquid. Electrochem Solid State Lett 10(3):D25. https://doi.org/10.1149/1.2409058

110. Durmus YE, Montiel GSS, Aslanbas Ö, Tempel H, Hausen F, de Haart LGJ, Kungl H (2018) Investigation of the corrosion behavior of highly As-doped crystalline $\mathrm{Si}$ in alkaline $\mathrm{Si}$-air batteries. ElectrochimicaActa 265:292-302. https://doi.org/10.1016/j. electacta.2018.01.145

111. Akerlof GC, Bender $P$ (1948) Thermodynamics of aqueous solutions of potassium hydroxide. J Am Chem Soc 70(7):2366-2369. https://doi.org/10.1021/ja01187a016

112. Balej J (1985) Water vapour partial pressures and water activities in potassium and sodium hydroxide solutions over wide concentration and temperature ranges. Int J Hydrog Energy 10(4):233-243. https://doi.org/10.1016/0360-3199(85)90093-x

113. Nickell RA, Zhu WH, Payne RU, Cahela DR, Tatarchuk BJ (2006) $\mathrm{Hg} / \mathrm{HgO}$ electrode and hydrogen evolution potentials in aqueous sodium hydroxide. J Power Sources 161(2):1217-1224. https://doi.org/10.1016/j.jpowsour.2006.05.028

Publisher's Note Springer Nature remains neutral with regard to jurisdictional claims in published maps and institutional affiliations. 